\title{
TOURISM MARKETING IN RUSSIA: STAGES OF FORMATION, MODERN STEREOTYPES AND SIMPLIFICATIONS
}

\author{
Sergey Volkov ${ }^{1}$
}

DOI: https://doi.org/10.31410/tmt.2019.235

\begin{abstract}
The article analyzes the stages of development of tourism marketing as a field of scientific knowledge in marketing theory. The author's attempt to rethink the stereotypes and simplifications developed in the theory and practice of tourism marketing, which hinder the active introduction of marketing technology in the system of strategic management of territories, is also undertaken. Methodological base of the present research was content analysis of fundamental works of domestic and foreign authors, which formed the basis of the theory of tourist marketing. Besides, comparative and analytical methods of research were applied. It is shown that the development of the basis of the theory of tourist marketing was based and was a logical continuation of the development of the theory of marketing services as a response to the process of formation of the economy of service type (economics of services). In the process of evolution of the theory of tourism marketing it has passed two stages. The first stage (1965 - mid-1990s) was devoted to the study of peculiarities of marketing activity in the sphere of tourism and hospitality at the level of microenvironment. The second stage begins in the mid-1990s with the study of marketing technologies at the level of meso-and macro-systems. On the basis of the carried-out analysis the conclusion about the productivity of the domestic theory of tourist marketing from foreign researches in this area is made. Also, the author distinguishes two main stages of development of the theory of marketing in tourism, which are characterized by the change of the object of study. The allocated stereotypes and simplifications in the theory of tourist marketing interfere with practical introduction of scientific workings out in this sphere in strategic management of tourist branch of the Russian regions.
\end{abstract}

Keywords: Tourism marketing, Tourism, Tourism Enterprises, Promotion, Tourist services, Tourist product, Stereotypes and simplifications in tourism marketing.

\section{INTRODUCTION}

I nitially, the theory of marketing developed with a focus on commodity production, and was aimed at maximizing the efficiency of material goods sales. However, with the intensive development of services, including tourism, as well as rapid transition from industrial to post-industrial model of development of national economies, marketers began to shift to the study of services as a specific management product.

Active formation of the service economy began after the late $40 \mathrm{~s}$ - early $50 \mathrm{~s}$ of the twentieth century. By the beginning of the XXI century, the service sector has become one of the most capital-intensive and profitable sectors of the economy. Thus, according to the World Bank Group, the share of the service sector in the global GDP in 2016 was $71 \%$. According to the World Travel \& Tourism Council, since 2005, tourism has become the largest and most dynamically developing sector of the services sector. Its share in the global GDP is $10.4 \%$ ( $\$ 8$ trillion). According to 2018 data, 319 million people worked in the tourism industry, i.e. every 10 employees in the world.

Faculty of Economics and Management, Volgograd State Technical University, Russia 


\section{THE GENESIS OF TOURISM MARKETING: FROM SERVICE MARKETING TO TOURISM MARKETING}

All the above circumstances predetermined the interest in the problems of marketing services both from the practice and from the scientific community. In the process of evolution of marketing theory, which was expressed in a stable trend of deepening and specialization of scientific developments, the marketing of services stood out in an independent field of scientific knowledge. As for the marketing of the tourist sphere (tourist marketing), it developed within the framework of the concept of marketing services and only in the early 90's of XX century was formed into a separate scientific direction within the framework of marketing theory, although some works on the specifics of tourist marketing began to appear long before that.

Thus, the first publication in the academic journal on the problem of tourism marketing appeared in 1968. Since then, the interest of scientists in the problems of development of the theory of tourist marketing has steadily increased (Figure. 1). Quantitative and qualitative leap in publishing activity on the problems of tourist marketing is observed since 2000. Thus, if in the period from 1968 to 1990, on average, 5 articles were published per year on the topic of tourist marketing, then since 2000 the average annual number of works devoted to the problems of marketing in tourism has increased to 218. It was during this period that we can speak of tourism marketing as an independent concept in marketing theory.

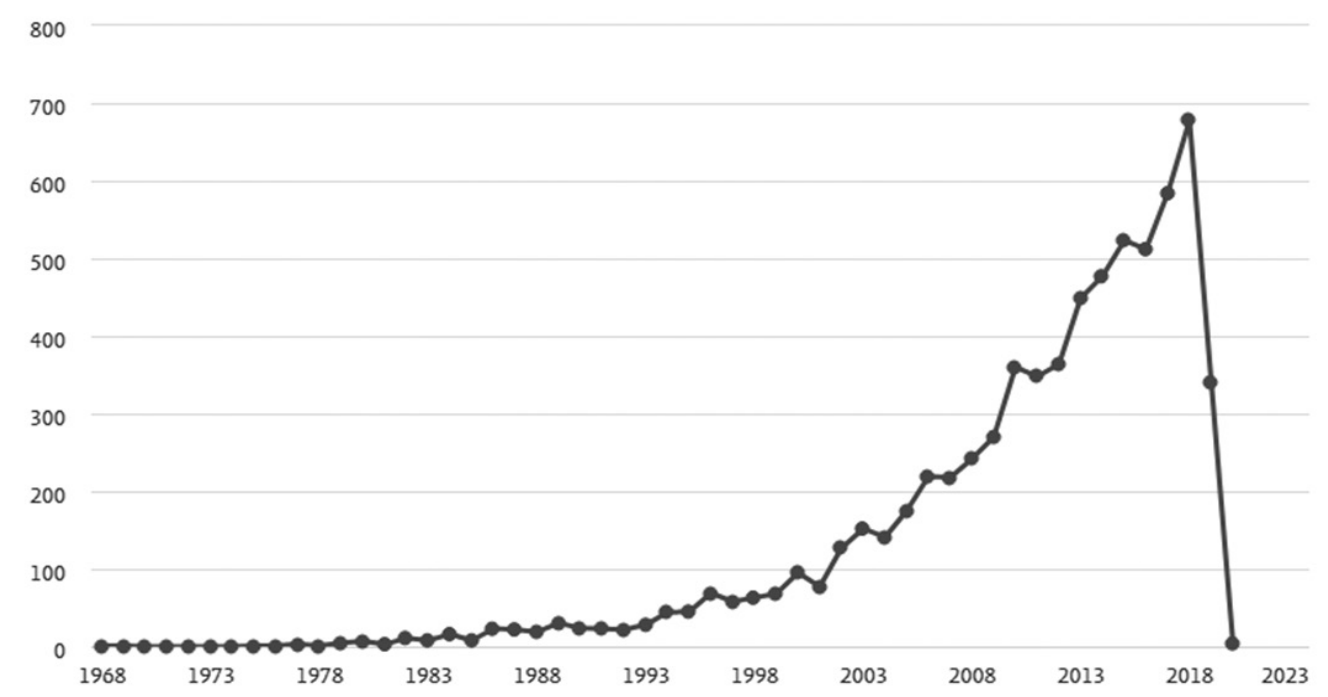

Figure 1. Number of publications on tourism marketing in international academic journals, 1968-2018

Source: based on Scopus database

Let's trace the evolution of tourism marketing through the prism of services marketing. The main stages of formation of the concept of services marketing are presented in Table 1.

The basic principles of service marketing were formulated by the American entrepreneur Cyrus $\mathrm{H}$. McCormick, who formulated such basic directions of modern marketing as market research and analysis, the basic principles of pricing and service and post-services. 
Table 1. The main stages of formation of the concept of marketing services

\begin{tabular}{|c|c|c|}
\hline Period & Basic content of theoretical works & Author \\
\hline End of the 1940s. & $\begin{array}{l}\text { Beginning of advanced development of the services sector compared to in- } \\
\text { dustrial production in the economies of a number of countries }\end{array}$ & \\
\hline 1969 & $\begin{array}{l}\text { Attempts to identify differences between goods in kind and services. Foun- } \\
\text { dations of the theory of service marketing }\end{array}$ & $\begin{array}{l}\text { E. Johnson } \\
\text { (University of } \\
\text { Washington, USA) }\end{array}$ \\
\hline $\begin{array}{l}\text { The end of the 60s } \\
\text { and the beginning } \\
\text { of the } 70 \mathrm{~s}\end{array}$ & $\begin{array}{l}\text { The contribution of the service sector to the GDP of developed countries has } \\
\text { become equal to that of the industrial and agricultural sectors }\end{array}$ & \\
\hline 1972 & Research on the application of the marketing concept in the service industry & $\begin{array}{l}\text { V. George } \\
\text { (University of } \\
\text { Georgia, USA) }\end{array}$ \\
\hline early '70s & $\begin{array}{l}\text { Numerous publications in the "Journal of Marketing" about the possibility of } \\
\text { separating the concept of marketing services in a separate discipline }\end{array}$ & $\begin{array}{l}\text { V. George, } \\
\text { H. Baxdale, R. Judd }\end{array}$ \\
\hline 1973 & Initiation of case studies on service marketing issues & $\begin{array}{l}\text { K. Lovelock } \\
\text { (Harvard Business } \\
\text { School, USA) }\end{array}$ \\
\hline 1974 & $\begin{array}{l}\text { The one-stage production, marketing and consumption of services is dis- } \\
\text { closed. Specificity of the service as a product is shown. For the first time a } \\
\text { new element of the process of marketing services is defined - the process of } \\
\text { interaction between those who provide a service and those who consume it. } \\
\text { The first book on service marketing "Introduction to Service Marketing" } \\
\text { was published. Problems of service marketing management caused by the } \\
\text { intangible nature of the service are revealed }\end{array}$ & $\begin{array}{l}\text { D. Ratmell, } \\
\text { E. Johnson } \\
\text { (University of } \\
\text { Washington, USA) }\end{array}$ \\
\hline 1976 & $\begin{array}{l}\text { A marketing model for "service in action" or "production of services" is pro- } \\
\text { posed. The basic characteristics of the service are singled out: simultaneous } \\
\text { production and consumption of the service and intangible }\end{array}$ & $\begin{array}{l}\text { E. Langheard, } \\
\text { P. Eiglier (University } \\
\text { of Marseille, France) }\end{array}$ \\
\hline 1977 & $\begin{array}{l}\text { Research of the peculiarities of the marketing concept in the sphere of pro- } \\
\text { fessional services. Initiatives to organize conferences on quality issues in } \\
\text { the field of services } \\
\text { The American Institute of Marketing published the first scientific report, } \\
\text { which covered the specifics of service marketing }\end{array}$ & $\begin{array}{l}\text { E. Gammesson } \\
\text { (University of } \\
\text { Stockholm, Sweden) }\end{array}$ \\
\hline Middle to late '70s. & Various service classifications are proposed & $\begin{array}{l}\text { J. Shostak, W. Sasser, } \\
\text { R. Olsen, T. Hill, } \\
\text { R. Chase } \\
\end{array}$ \\
\hline 1979 & $\begin{array}{l}\text { The function of marketing in the sphere of services is revealed. Specific } \\
\text { features of the concept of marketing services are defined. The concepts of } \\
\text { "internal marketing", "two-way marketing" are introduced into scientific } \\
\text { circulation }\end{array}$ & $\begin{array}{l}\text { C. Gronroos } \\
\text { (Swedish School } \\
\text { of Economics } \\
\text { and Business } \\
\text { Administration) } \\
\end{array}$ \\
\hline 1980 & $\begin{array}{l}\text { The generic distinction between a service and a physical commodity is de- } \\
\text { termined }\end{array}$ & L. Berry \\
\hline 1981 & $\begin{array}{l}\text { The first national conference on service marketing organized by the Ameri- } \\
\text { can Marketing Association (AMA) was held }\end{array}$ & \\
\hline 1984 & $\begin{array}{l}\text { A separate section has been set up at AAM to deal with service marketing } \\
\text { issues }\end{array}$ & \\
\hline The '80s. & Formation of the theory of public organization services marketing & $\begin{array}{l}\text { C. Lovelock, } \\
\text { C. Weinsberg } \\
\text { (Harvard Business } \\
\text { School, USA) }\end{array}$ \\
\hline 1985 & $\begin{array}{l}\text { Establishment of the Center for Service Marketing Studies at the University } \\
\text { of Arizona (USA) }\end{array}$ & \\
\hline 1990 & The first international seminar on service marketing management was held & $\begin{array}{l}\text { University of } \\
\text { Marseille (France) }\end{array}$ \\
\hline Early'90s. & The first Russian publications on the problem of services marketing appeared & $\begin{array}{l}\text { Innovators E.V., } \\
\text { Markova V.D., } \\
\text { Tul'chinsky G.L. }\end{array}$ \\
\hline
\end{tabular}

Source: Khlebovich, D.I. \& Burmenko, T. D. (Ed.). (2007). Service sphere: marketing. Moscow: Knorus 
Till the middle of 80th years of XX century there is an active scientific polemic about expediency and necessity of separation of marketing of services from the general theory of marketing. The question about the criteria of division of material goods and services remained controversial and debatable. For the first time the main generic difference between services and physical goods was given by Leonard Berry in 1980. In his paper „Services Marketing is Different”, L. Berry says that ,a physical commodity is an object, device or thing, while a service is a deed, performance or effort". Thus, the author deduces the main difference between goods and services - intangible.

Today, there are several well-known and recognized scientific schools of marketing services in North America and Western Europe. North American schools play a leading role among them. One of the oldest of these schools was founded as the Center for the Study of Service Marketing (CIMU) at the University of Arizona (USA).

Another famous North American school of marketing services is Texas A\&M University. This school is represented by the works of three productive colleagues, Leonard Berry, Valeria Zeithaml and Parsiu Parasuraman. These scientists are the authors of the North American model of service quality and its popular measurement SERVQUAL methodology.

Harvard Business School has also played a role in the development of service marketing as an independent scientific discipline. The leaders of this school are Christopher Lovelock, Charles Weinsberg and John Bateson.

Among the Western European schools of marketing services there are two schools: The Northern School and the Marseilles School. The Nordic School is represented by the works of two undisputed leaders: Evert Gummesson and Christian Gronroos.

Another European school, conditionally called „Marseille” by the name of the famous French university, is represented by veterans of service marketing E. Langeard and P. Eiglier.

As in the case of general marketing theory, the concept of tourism marketing was based on the extensive practical experience of entrepreneurial structures. In the process of rapid development of tourism sphere after the Second World War, complication of forms and methods of competition, entrepreneurial structures faced the need to study their consumers and the formation of loyalty to demand.

Initially, all tourism business was mainly focused on sales of the existing product. The unprecedented popularity of packaged tours in the $60 \mathrm{~s}$ was the result of the ingenuity of entrepreneurs, who saw the possibility of reducing the cost of recreation through the use of unsold seats in the aircraft. It is not surprising that the first tour operators did not need to apply marketing technologies, as the quality of the product was constantly growing, and if the prices were kept under control, it was possible not to worry about the level of demand, it showed a steady trend to increase. At the same time, excessive demand also creates certain difficulties for the development of companies. The popularity of packaged holidays abroad soon led to the need to expand the range of products and differentiate the supply. In many resorts there were large-scale construction of hotels and other accommodation facilities, most of which did not meet the standards of either comfort or quality of service. Tourists were concerned not only about the quality of accommodation, but also about the activities of air carriers. 
As noted in the monograph „Tourism Marketing” by the English researcher J. Christopher Holloway, ,the management of travel companies began to realize that it is impossible to achieve an optimal level of sales without overcoming three widely spread phobias in society: fear of flight; fear of unusual food; fear of foreigners".

Passenger flights served old, technically obsolete aircraft; due to the strict pricing policies of public carriers and bilateral agreements, it was necessary to resort to unsuitable, technically and operationally inappropriate airports. The concept of cheap and frequent flights has been replaced by the understanding that it is much more advantageous to purchase new vehicles, which, thanks to their high coefficient of technical use and greater capacity, reduce operating costs and, above all, guarantee the safety of passengers.

In the mid-60s and early 70s, consumers of tourism services were characterized as conservative. Globalization processes were only just beginning to gain momentum and intercultural and interethnic interactions were in their infancy. Tourists were afraid of everything new, especially in the field of food. The process of catering caused a problem both for tourists and hotel owners. The problem was solved by specialists who suggested how to organize the process of public catering in hotels in the most efficient way by changing the ways of cooking, serving and presentation of dishes. As payroll costs increased, more and more hotels switched to a buffet system, which provided for an independent choice of dishes. As a result, additional costs were offset by significant savings in service costs and reduced food waste. In the mid-1990s, the buffet concept was replaced by the all-inclusive concept, however, a reversal of the previous one, but only an addition to it, especially in the resort recreation segment.

Fear of foreigners is often due to a lack of understanding of local customs and behaviour. In the 70's, the largest UK travel companies came to the conclusion that the only way to overcome the barrier is total control over the living conditions and quality of service. They have invested heavily in the construction of their own hotels and hired experienced and qualified managers who have raised the standards of service to a new level. Where once the role of resort representatives was to accompany tourists from the airport to the hotel and back, as well as to sell excursions, now they have become qualified service personnel, designed to provide maximum assistance to the client in order to meet his needs. More attention has been paid to training tourism managers in the basics of business communication, psychology and sales techniques.

The increasing complexity of the interaction of tourism market players, the increasing level of competition and demands from consumers (tourists), and the numerous practical cases demanded a deep theoretical understanding and systematization of the available knowledge about the specifics of the tourism industry.

One of the first theoretical works in the field of tourism marketing is a monograph by G. Shelenberg „Marketing y Turismo”, which was published in 1965 at the Institute of Tourism Research in Madrid. In 1971, the work of one of the founders of tourism marketing, Joost Krippendorf, was published in Switzerland - „Marketing et tourisme”, which considers the importance of applying tourism marketing methods and tools. Later, in 1987, this work was completed and updated by the author and reprinted in France. Not surprisingly, Spain was the first country to have a theory of tourism marketing. The fact is that it was in Spain that the first ministry in Europe appeared, which dealt with the issues of support and development of tourism at the national level. 
Joost Krippendorf is considered to be the classic and founder of the concept of tourism marketing, which defines him as ,a systematic and coordinated business activity of a private or public enterprise at the local, regional, national or international level, carried out in order to achieve optimal satisfaction of the needs of consumer groups and their motivation to make a second purchase". This definition of tourism marketing reflects the essence of the concept, which is based on the principle of satisfying the needs of consumers of tourism services (tourists) while at the same time making a profit for tourism service providers. At the same time, the author stresses the importance of systematic and coordinated action by business services at the local, regional, national and international levels to establish long-term relationships with tourists.

In another equally conceptual work by the French researcher Jean-Jacques Schwartz, „Marketing Approach to Tourism Development” („Pour un approche maketing de la promotion touristique"), tourism marketing is seen as a process of finding and identifying an optimal market based on the real and potential needs of the consumer in order to improve the competitive advantage of the tourism company. The author does not contest the idea expressed by J. Krippendorf on the importance and necessity of meeting the needs of tourists, complements this conclusion with the conclusion that it is advisable to identify consumer preferences through market research. Thus, in the theory of tourist marketing there appear works which appeal to necessity of permanent studying, revealing and formation of tourist preferences that further will be a basis of modern concepts of territorial development of tourist industries.

Previously, a similar idea was expressed by the Romanian geographer economist Eugenio Nicolescu Eugeniu in his work „Marketing in Tourism”. The researcher considered tourism marketing «as a policy of a travel company or organization based on the constant study of current and future travel preferences - specific methods and technologies - aimed at the constant adaptation of the offer to these requirements, in order to better satisfy them in order to develop business in specific market conditions»). Although the last two approaches more fully reflect the essence of tourism marketing, expanding its scope and application, they cannot be considered comprehensive.

As a more complete definition can be considered the one proposed by Canadian experts Tocquer Gerard and Zins Michel, who give the following definition of tourism marketing in their work „Marketing du tourism” (Marketing du tourism): „Marketing in tourism is a process in which the structure of tourism demand is expected and satisfied by the development of the product (service), distribution, the setting of the exchange rate (price of the tourism product), the existence of a link between the tourism organization and its target markets, in order to best serve the interests of the company and consumers". This definition reveals an additional aspect of the marketing approach, offering a broad image of the marketing activities of the tourist enterprise.

Until the early 1990s, academic marketing science focused exclusively on the specifics of marketing activities in the field of tourism and hospitality at the microenvironmental level. The global economic and geopolitical transformations of the early 1990s (the conflict in the Persian Gulf, the end of the Cold War, the collapse of the USSR, the formation of new independent states, etc.), as well as the high rate of scientific and technological progress (primarily the development of electronics and communications) naturally affected the focus of marketing research. Research (mainly in the form of scientific articles in academic journals) began to appear, in which the problem of assessing the impact of the macro-environment on the quality of tourism services began to be studied. Gradually, a systematic approach to the description of conditions for ensuring quality and sustainable development of the tourism industry at the level of territo- 
ries (countries, regions, cities, municipalities, etc.) is being implemented. The issues of creation, management and promotion of the national tourist product (brand) to foreign markets are becoming the key issues on the agenda of the theory of tourist marketing.

Since the mid-1990s - early 2000s, a strategic shift in the object of tourist marketing research has been taking place in the foreign academic environment. If before that, the main part of researches was devoted to the analysis of marketing activity at the level of tourist firms and organizations, ensuring the competitiveness of entrepreneurial structures in the field of tourism and peculiarities of marketing communication between participants of tourist exchange, from the beginning of the 2000s began to appear the works which investigated tourist territories as the object of promotion. The focus of research is shifting from individual firms to the peculiarities of the formation of territorial policy for the development and promotion of unique tourist properties as competitive advantages of the territories in the struggle to attract tourists. Global and multistructural competition forces the territories to develop new marketing methods and technologies of attracting tourists and forming sustainable incentives for them to make repeated trips.

At the moment we can speak about a number of established scientific centers to study the specifics of tourism marketing (Figure. 2). The leading positions in this list are held by Hong Kong Polytechnic University and Hotel and Tourism Management School in Hong Kong. The rest of the places are distributed among American, Australian and European universities. It is noteworthy that in the list of 50 research centers with the largest number of registered in international scientometrics databases of scientific articles on the problems of tourism marketing there are no Russian universities or research centers. This fact allows us to conclude that Russia has not developed a full-fledged scientific school of tourism marketing. This is also evidenced by the number of articles registered by Russian authors in international scientometrics databases (Figure. 3).

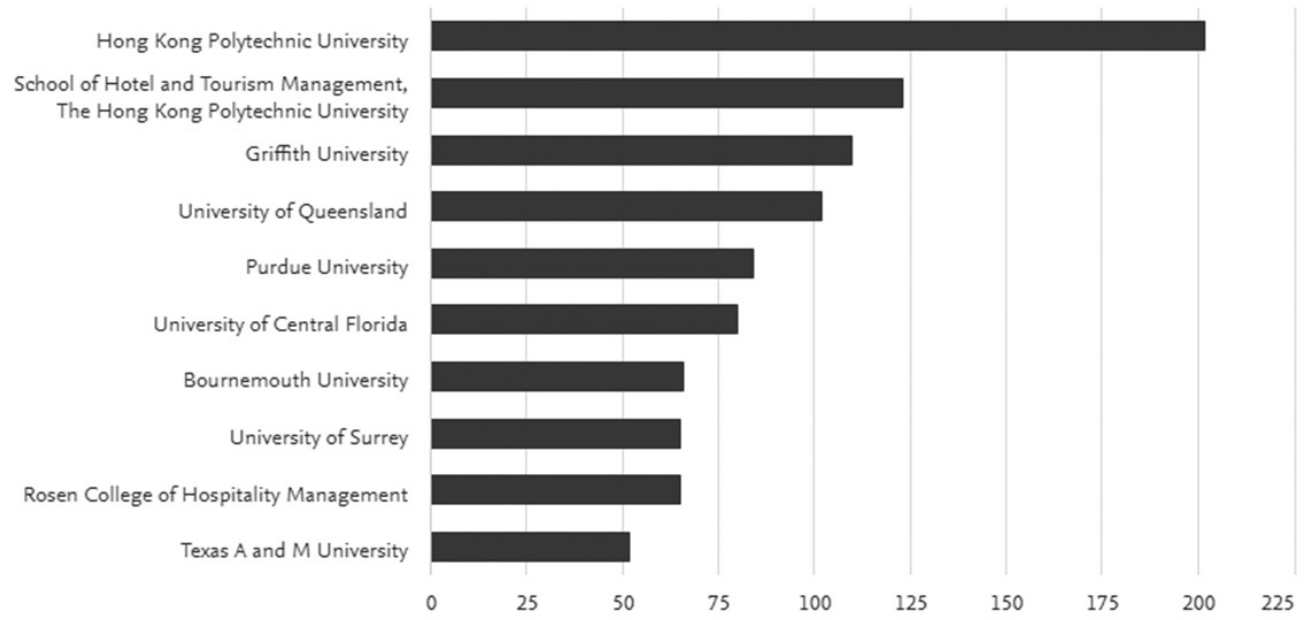

Figure 2. Scientific centers with the largest number of registered scientific articles on the problems of tourist marketing, 1968-2018

Source: based on Scopus database

A number of specialized scientific periodicals have been created in the foreign scientific environment, which publish the most relevant researches in the field of tourism with a great emphasis on the problems of tourist marketing (see Figure. 4). In the domestic academic environment, such examples can be found in scientific publications of the Russian State University of Tourism and Service („Modern Problems of Service and Tourism”, „Service plus”, „Service in Russia 
and abroad”, „Herald of the Association of Higher Education Institutions of Tourism and Service”), as well as „Herald of the National Academy of Tourism”. However, these scientific journals mainly specialize in the general problems of tourism development and do not pay enough attention to the problems of marketing, which does not allow to attribute these publications to the specialized problems of tourism marketing.

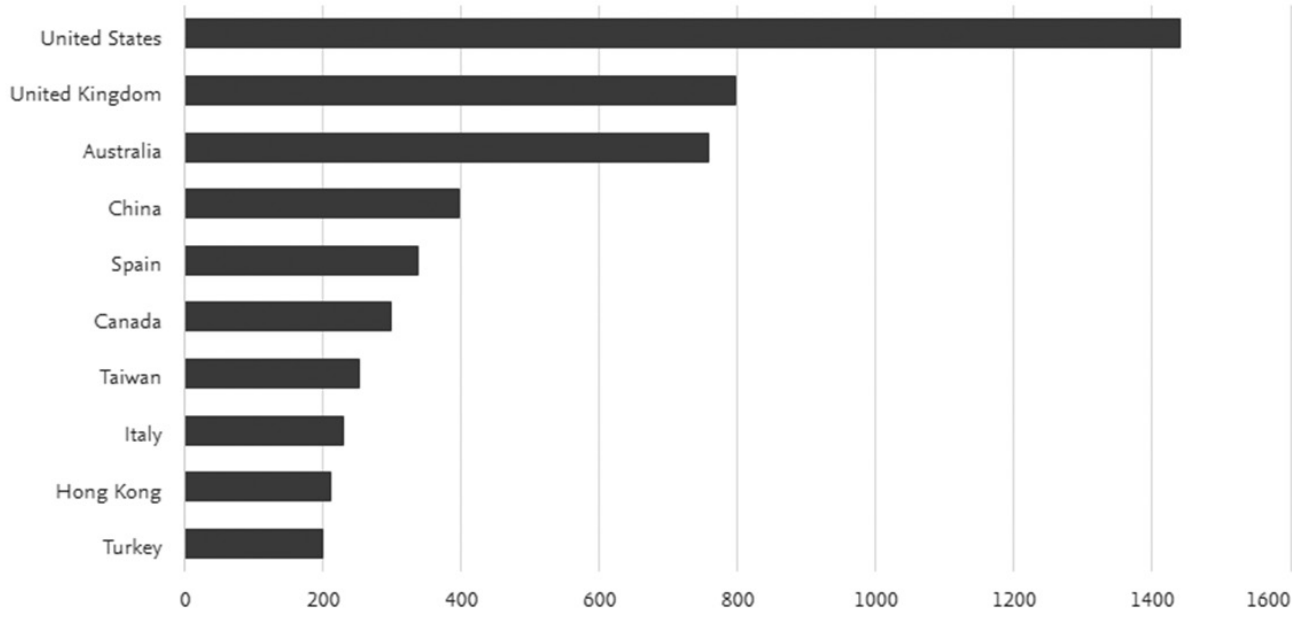

Figure 3. Nationality of the authors of the articles on the problems of tourist marketing, 1968-2018

Source: based on Scopus database

30

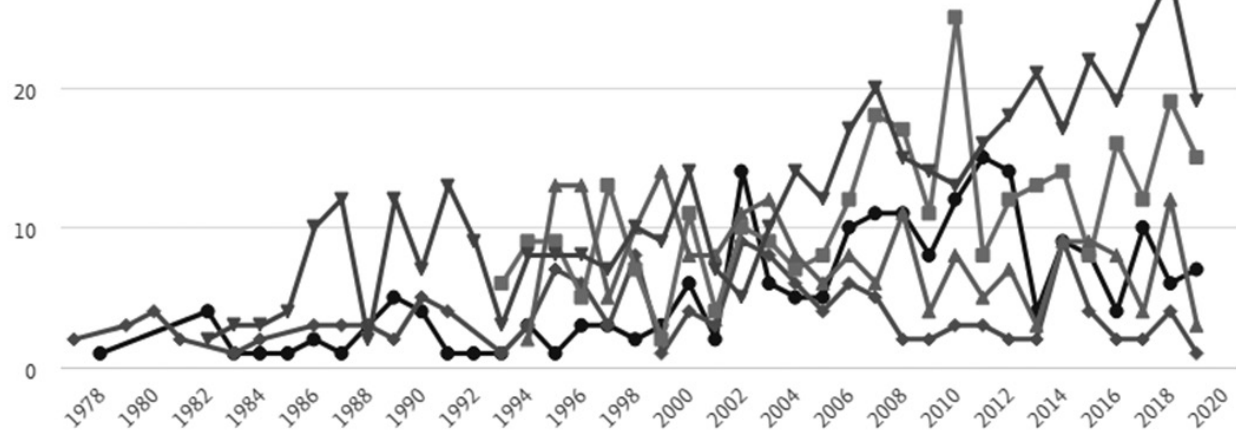

- Journal Of Travel Research $\leadsto$ Annals Of Tourism Research $\quad$ - Journal Of Travel And Tourism Marketing \pm Journal Of Vacation Marketing $\rightarrow$ Tourism Management

Figure 4. The most authoritative professional journals on tourism marketing issues

Source: based on Scopus database

In Russian science, the concept of tourism marketing began to develop in the early 1990s with the appearance of translated works of Western researchers. The presence in the tourism system of a large number of unprofitable and unprofitable enterprises was the reason for the development of methodological recommendations on the basics of tourism marketing, which were proposed by specialists and experts of the Central Council for Tourism and Excursions, the Department of tourist agencies and routes, as well as researchers of the All-Union Research Laboratory on Tourism and Excursions. This work was an attempt to develop the basic marketing principles for tourism enterprises, which passed from the planned method of economic activity to the market mechanism of functioning. The tourism industry is beginning to be 
considered and studied not as a social phenomenon, but as a branch of the economy with high entrepreneurial and financial and economic potential.

The authors of the mentioned methodical recommendations, highlight the perspective, in the new conditions of management, ways of using marketing in the activities of the tourist enterprise. Among the main ones:

1. development of a complex tourist product;

2. softening the acuteness of seasonal excess of demand over supply;

3. development of additional paid services for tourists;

4. specialization of the economy in the production of certain types of tourism products, or in work with narrow sectors of the market.

In addition, the work focuses on the development of practical recommendations for the use of the basic principles of the establishment and operation of the commercial and marketing service of the tourism enterprise. Distinctive features of the analyzed methodical recommendations are, firstly, high practical orientation of recommendations for increasing profitability and competitiveness of business structures in the sphere of tourism in the conditions of transition of national economy to the market model of development, and secondly, absence of the generally accepted marketing terminology that testifies to the embryonic stage of development of the theory of tourist marketing in Russia.

One of the first Russian works devoted to the problem of application of marketing tools to increase the competitiveness of subjects of the tourist market is the textbook of D.K. Ismaev „Fundamentals of strategy and planning of marketing in foreign tourism”. In it the author considers the general concept of marketing in relation to tourism. The issues raised in the paper are considered in relation to the activities of tourism firms and organizations. A distinctive feature of this study is the author's focus on the analysis of marketing technologies and models in relation to those travel agencies that are engaged in organizing the reception of foreign tourists in Russia. In other words, the author points to the need to implement the marketing concept to attract foreign tourists, not to develop competition among tourism firms and organizations organizing the departure of compatriots abroad. This feature can be explained by the influence of the Soviet legacy of tourism development, which was aimed primarily at the development of inbound tourism, rather than outbound tourism. This thesis is gradually leveled out in the subsequent works of domestic researchers. The main task of tourism marketing, according to D.K. Ismaev, should be ,advertising and other commercial activities that contribute to the consolidation and development" of positive trends in tourism. However, he entrusts this task exclusively to business entities, which, in his opinion, ,should seek ways to influence the legislative and executive bodies at all levels in order to draw their attention to the need to create more favorable conditions for the reception of foreign tourists". This approach, we believe, is not comprehensive and inefficient, as it significantly reduces the scope of marketing technologies and excludes a number of tools for the development of tourism, in particular, the tool of public-private partnership.

Special mention should be made of the work of A.T. Kirillov and L.A. Volkova „Marketing in tourism", which can be considered the first in the domestic theory of tourism marketing research of systemic, complex and structured nature. The authors, based on the study of domestic and foreign experience, analyze the main categories and concepts of the tourist market, forms and methods of sales of tourist products. Besides the general questions of tourist marketing, such as the role of marketing in the activities of a tourist company, the specifics of marketing tour enterprise and the process of organizing and conducting marketing research, the authors make the first 
attempt to study the impact of tourism on regional development. The monograph explores the relationship between the tourist attractiveness of the region and the level of tourism development in it. The role of tourism enterprises (travel agencies and tour operators) in the system of territory development is defined. Researchers assign a special role to the process of marketing research as a strategic tool to improve the economic efficiency of the tour enterprise and the development of the tourism market in the region. This monograph is the first domestic work trying to move from the analysis of the tourism industry from the micro-level to the macro-level.

V.B. Saprunova's paper „Tourism: Evolution, Structure, Marketing”, based on the example of European countries (primarily Germany and Switzerland), considers the problems of evolution, structure and regulation of the tourism market. The paper also considers the main features of a new consumer of tourism services, analyzes his motivation and behavioral characteristics. Of particular interest are the issues of practical marketing, which in addition to the micro-level (tour operators and travel agencies) is analyzed at the institutional level (the division of marketing functions between government agencies, industry associations and entrepreneurs). The author makes one of the first attempts in domestic science to move from the analysis of marketing activities of travel agencies to the analysis of the national marketing strategy of the industry. V.B. Saprunova singles out the key features of tourism marketing, to which she refers:

1. not to stimulate demand for tourism services, but to manage demand;

2. a high degree of reliability of information on tourism products;

3. consumer protection;

4. the special role of marketing in the off-season period (diversification of tourism products);

5. the central role of psychological, behavioral and social characteristics of the consumer;

6. coordination of marketing of participants in the tourism market.

And although the peculiarities of the author's tourist marketing are not subject to deep system analysis, they formed the basis for many further domestic scientific researches in this aspect of the problem.

One of the first systematic works in the national concept of tourist marketing is the textbook „Marketing in tourism: a strategy for success" by Professor of the Russian Economic University named after G.V. Plekhanov, T.P. Rozanova. The author analyzes the marketing concept from the perspective of a travel company. On the basis of the analysis of foreign and domestic experience of development of the tourist market, methodical approaches to development of the concept of marketing in tourism are formulated. T.P. Rozanova singles out 8 main stages in the process of realization of tourist marketing by travel agencies: analysis of strengths and weaknesses of the enterprise; analysis and choice of tourist products; identification of possible target markets; ranking of selected markets; thorough (deep) analysis of selected markets; development of a marketing plan; use of the marketing plan; observation and monitoring of the use of tourism companies. Tourism advertising is seen as one of the most important elements of tourism marketing. The conclusion to which the author comes as a result is interesting - tourist marketing is more of an art than a science. In this regard, ,requires from the one who uses its methods in their practice, a creative approach to each problem encountered by him and, as a rule, a non-standard solution to the relevant practical problems".

The most complex work devoted to the problems and specifics of tourist marketing is the textbook by the Belarusian authors A.P. Durovich and A.S. Kopanev - „Marketing in tourism”, which was subsequently repeatedly reprinted and even recommended by the Ministry of Edu- 
cation of the Russian Federation as a teaching aid for students of higher education institutions studying in the areas and specialties - „Management”, „Marketing”, „Management in the social sphere". In this textbook the authors on the basis of general scientific methods and theories of marketing disclose the essence, principles of marketing, its functions and technology of marketing activities of the tourist enterprise. This work is a classic example of fundamental work, without original ideas and is a basic textbook in the field of tourism marketing. The main subjects of tourist marketing are travel agencies and tourists.

Subsequent works expand the composition of subjects of tourist marketing, including, in addition to travel agencies and tourists, accommodation facilities (hotels), catering facilities (cafes, restaurants) and business structures.

One of the first domestic researchers, who began to purposefully and systematically study the problems of economics and marketing in the tourism industry, not from the standpoint of individual firms and enterprises, but from the standpoint of territories is a professor of the Russian Economic University named after G.V. Plekhanov - Dzhanjugazov E.A. Her work - „Marketing of tourist territories" - is distinguished by its non-triviality and great practical value due to the complex and systematic approach to the problems under consideration. The author in his work researches the basic elements of the complex of marketing of tourist territories, and also considers methods of formation and promotion of a territorial tourist product taking into account regional features. The novelty of the approach lies in the strategic symbiosis of territorial and tourist marketing for the formation and promotion of the regional tourist product to external and internal markets.

The majority of domestic scientific works in the field of tourism marketing are either of a clarifying nature or in the form of practical cases for specific territories. Recently, the scientific direction of studying of tourist branding or branding of tourist territories has been actively developed.

In spite of the large number of publications in the Russian scientific sphere concerning tourism marketing, almost all researches are limited exclusively to the interpretation of the role of marketing technologies in the development of tourism at various levels (micro-, meso- and macrolevels). The domestic marketing theory is based on the adaptation of the methodology of foreign authors in the field of services marketing and tourist marketing. Unfortunately, there are no unique methods and models of tourism development based on the concept of tourism marketing. Attempts to adapt foreign methodological developments and implementation of marketing strategies for the development of the tourism industry do not look convincing and weakly effective due to its practical detachment from the specifics of the domestic market of tourism services.

Thus, we can conclude that in the process of evolution of the theory of tourism marketing, it has gone through two stages. The first stage (1965 - mid-1990s) was devoted to studying the peculiarities of marketing activities in the field of tourism and hospitality at the level of microenvironment (travel agencies, tour operators, tourists). The research was conducted on the examples of specific firms and companies. Since the mid-1990s, the process of studying marketing technologies at the level of mezzanine and macro-systems has started. The impact of state policy on the development of national tourism industries is studied. Within the framework of the theories of regional economy, a specific tourist area is considered as a product of promotion in tourist markets. The focus of marketing research shifts towards territorial branding strategies and promotion of national tourism products. 


\section{STEREOTYPES AND SIMPLIFICATIONS IN TOURISM MARKETING}

On the basis of the analysis of more than 200 scientific articles on the problems of tourism marketing in Russia, it is possible to highlight a number of stereotypes and simplifications that have firmly entered the practice of tourism marketing and hinder the effective implementation of the marketing approach to the system of strategic management of territories. One of the main stereotypes, which is actively replicated both in the scientific and expert community and among the general public, is a myth that marketing is a panacea for all problems of the tourism industry. According to the logic of this stereotype, with the help of marketing tools (most often, it all comes down to advertising tourism opportunities and branding of the territory) it is possible to solve the problems of development of the tourism industry. As Professor Belskih I.E. rightly points out, ,image strategy is important for the initial attraction of tourists to the territory of the country. In order to retain customers, it is necessary to develop tourism infrastructure". In order to retain and meet the needs of tourists, it is necessary not only to form and develop a positive image, but also an appropriate level of socio-economic and engineering infrastructure of the area.

The logical continuation of the above stereotype is a simplified attitude to the personnel potential of those responsible for the implementation of marketing activities in the field of tourism development - marketing in tourism, as well as marketing in general, can be engaged in anybody. There is a well-established perception of a marketer as a creative person with a predominantly humanitarian education, who is only engaged, which fountains crazy ideas to achieve the wow-effect. Such simplification considerably complicates the process of formation of complex marketing strategies of regional tourism development taking into account modern technologies and means of communication. Marketing in tourism is a complex, multistage process, which requires a systematic and interdisciplinary approach. Recently, due to the rapid technological development, a special urgency and demand in the system of tourist marketing is given to technical specialists.

The fragmented marketing approach to managing the Territory's tourism potential is a critical simplification in the process of regional tourism development. Fragmentation is manifested both in the system of territorial management (separate structural subdivisions responsible for the marketing of territories instead of the through orientation of the entire management system), and in the process of implementing a set of marketing activities. Very often the marketing approach to the management of tourist potential of the territory is reduced to a set of separate, often logically unrelated elements of marketing strategy. Thus, often, the practice of tourist marketing ignores the research of the market and consumers, reducing all marketing activities to advertising campaigns, which significantly reduces the effectiveness of the marketing complex. For the effective development of territorial tourist and recreational complexes it is necessary to have a systematic approach, which ensures the synchronization of strategic planning of territory development with the available tourist potential.

Marketing in tourism does not require large financial resources - another common myth, which is clearly manifested in the fragmentation of the marketing approach to managing the tourism potential of the territory. Russian regional government officials, for some reason, are convinced that marketing does not require large investments. This is partly explained by the low level of marketing competence of the majority of regional and municipal level managers. Many managers do not quite understand the essence and principles of territorial marketing, hence the inability to organize and implement marketing mechanisms of tourism development in the regions. Content analysis of strategic documents for the development of tourist and recreational 
complexes in the regions of the Southern Federal District has revealed the problem of lack of funds allocated for marketing campaigns to promote the tourist opportunities of the territories, and in some regions, such as in the Volgograd region, for the advertising of tourist potential is not planned any funds. Lack of market approach to the process of organization and management of tourist and recreational complexes of the Russian territories is a deterrent.

Standard marketing tools used in the process of managing the tourist potential of the territory is an institutional simplification, which directly affects the efficiency of development of tourist and recreational complexes of Russian regions. Within the framework of this study, we consider standard marketing tools to be advertising of tourist destinations and their possibilities in various media, as well as classical PR tools (Internet, business events, social projects, etc.). The author wrote in detail about the necessity of non-standard methods of positioning, including from the point of view of tourist opportunities, as well as about foreign experience of promotion of territories in his previous works.

The hope for a rapid impact of tourism marketing activities is another conceptual stereotype and simplification. Russian officials responsible for the development of tourism, for some reason, believe that the result of the investment in marketing (insignificant) should be tangible and quickly manifested. At the same time, as a rule, only the economic effect from the implementation of marketing activities is evaluated and the social effect is completely ignored - the increase in the level of residents' involvement in the processes of territorial development, the increase in the level of residents' and non-residents' loyalty to the tourist product of the territory, the formation of a favorable image, the increase in the level of comfort of living, etc.

The main conclusion of this study is that in Russian reality, marketing in tourism is a purely scientific direction that does not have a real request from the practice and regional management. The asynchronous development of the theory and practice of tourism marketing is obvious. Numerous scientific researches and recommendations of scientists have no applied potential, because of the lack of real interest on the part of officials responsible for the development of this sector of the economy.

Lack of end-to-end marketing orientation in the process of managing the development of tourist and recreational complexes of Russian territories affects the quality of tourism development, the intensity of tourist flows to the regions and, as a consequence, the missed synergetic effect of the development of related sectors of economy.

\section{ACKNOWLEDGMENTS}

The reported study was funded by RFBR, project number 20-010-00072.

\section{REFERENCES}

Barashev, A. F. (2009). Marketing in tourism and hospitality. Moscow: Finances and Statistics. Belskikh, I.E. (2009). Territorial strategies of the image of the tourist business in the world economy. Regional economy: theory and practice, 8, 67.

Berry, L. (1980, May-June) Services Marketing is Different. Business, 30, 24-29.

Bramwell, B. \& Rawding, L. (1994, December). Tourism marketing organizations in industrial cities. Organizations, objectives and urban governance. Tourism Management, 15(6), 425-434. 
Chernyakina, A. O. (2012). Tourist territory branding: mistakes and key aspects of creation within the framework of the cluster approach to tourism development. Vestnik of the Tomsk State Pedagogical University, 12(127), 47-52.

Chon, K. S. (1991, March). Tourism destination image modification process. Marketing implications. Tourism Management, 12(1), 68-72.

Coles, T. (2003). Urban tourism, place promotion and economic restructuring: The case of post-socialist Leipzig. Tourism Geographies, 5(2), 190-219.

Crockett, S.R. \& Wood, L.J. (1999). Brand Western Australia: A totally integrated approach to destination branding. Journal of Vacation Marketing, 5(3), 276-289.

CSB Tourist. (1991). Basics of tourism marketing. Moscow: Author.

Dadalova, M.V. (2010). Peculiarities of formation of the tourist marketing. Belgorod Economic Bulletin, 1(57), 17-20.

Durovich, A. P. \& Kopanev, A. S. (1998). Marketing in tourism: textbook for universities. Minsk: Ekonommpress.

Dzhanjugazova, E.A. (2006). Tourist Area Marketing: a manual for higher education students. Moscow: Publishing Center „Academy”.

Faulkner, B., Oppermann, M. \& Fredline, E. (1991). Destination competitiveness: An exploratory examination of South Australia's core attractions. Journal of Vacation Marketing, 5(2), 125-139.

Goloshchapova, T.V. (2008). Marketing researches of the hotel services market (on the example of Togliatti). Vestnik Povolzhsky State University of Service. Series: Economics, 4, 47-54.

Gronroos, C. (1979). Marketing of Services: A Study of Marketing Function of Service Firms: Unpublished Econ. D. dissertation. Stockholm: Swedish School of Economics.

Gronroos, C. (1983). Strategic Management and Marketing in the Service Sector. Cambridge, MA: Marketing Science Institute.

Gross, D. (1997). Greatest Business Stories of All Time. First edition. New York: John Wiley \& Sons, Inc.

Gummesson, E. (1977). The Marketing and Purchasing of Professional Services. Stockholm: Marketing Technology Center.

Hall, D. (1999). Destination branding, niche marketing and national image projection in central and Eastern Europe. Journal of Vacation Marketing, 5(3), 227-237.

Hollier, R. (1991, March). Conflict in the gulf. Response of the tourism industry. Tourism Management, 12(1), 2-4.

Holloway, J.K. (2008). Tourist Marketing: 4th Edition. Kiev: Znannya.

Ismaev, D.K. (1994). Fundamentals of strategy and marketing planning in foreign tourism. Moscow: Beam.

Kazantsev, Yu.Yu. (2012). The role of territory marketing in increasing the tourist attractiveness of the region. Interexpo Geo-Siberia, 3, 65-69.

Khlebovich, D.I. \& Burmenko, T. D. (Ed.). (2007). Service sphere: marketing. Moscow: Knorus.

Kirillov, A.T. \& Volkova, L.A. (1996). Tourism marketing. St. Petersburg: Publishing house of the St. Petersburg University.

Koshurnikova, Yu. E. \& Kalyuzhnova, N.Ya. (2012). Marketing of interaction in the tourism industry (on the example of the Irkutsk region). Vestnik Irkutsk State Technical University, 11(70), 229-235.

Krippendorf, J. (1971). Marketing and tourism. Bern: Herbert Lang.

Krippendorf, J. (1987). Marketing and tourism. Paris: University Presses of France.

Langeard, E. \& Bateson, J. (1981). Services Marketing: New Insights from Consumers and Managers. Cambridge, MA: Marketing Science Institute. 
Langeard, E. \& Eiglier, P. (1976). Principles of marketing policy for service companies. France, Marselle: The Institute of Administration of Enterprises, University of Aix-Marselle.

Latortsev, A. A. (2011). Promotion of the national tourist product using the state tourist branding. Scientific Bulletin of MGIIT, 2, 24-28.

Lesnik, A.L. (2007). Hotel marketing. Theory and practice of the sales maximization. Moscow: Knorus.

Marinov, S. (2013). Marketing Department of Tourist Destination. Service in Russia and abroad, 8(46), 98-103.

Nicolescu, E. (1975). Marketing in tourism. Bucharest: Sport-Tourism Publishing House.

Novatorov, E.V. (2002). Development of marketing services as an independent scientific discipline abroad. Marketing in Russia and abroad, 4, 5.

Parasuraman, A., Zeithaml, V. \& Berry, L. (1985). A conceptual model of service quality and its implications for future research. Journal of Marketing, 49, 41-50.

Parasuraman, A., Zeithaml, V. \& Berry, L. (1988) SERVQUAL: a multiple-item scale for measuring consumer perceptions of service quality. Journal of Retailing, 64, 12-40.

Peters, M. (2013). Strategic brand management of tourist destinations. Vestnik RMAT, 2(8), 11-21.

Rafailova, G. (2012). The importance of marketing for the sustainable development of tourism specialization. Issues of economic structuring, 2, 17-21.

Ramona, G., Pirvu, G. \& Nanu, R.A. (2009) Tourism marketing and brand management perspective in Romania. Metalurgia International, 14(11), 140-142.

Rozanova, T.P. (1998). Marketing in tourism: strategy for success. Moscow: Plekhanov REA.

Saprunova, V.B. (1998). Tourism: evolution, structure, marketing. Moscow: Axis-89.

Schwartz, J.J. (1984). For a marketing approach to tourism promotion. France: Lausanne.

Semenova, L.V. (2014). Trends and prospects of tourism marketing development in Stavropol region. Science Park, 2-2(22), 100-105.

Tock, G. \& Zins, M. (1987). Marketing of tourism. Canada: Gaetan Morin Publisher.

Travel and Tourism: Economic Impact. (2018). London: World Travel \& Tourism Council.

Turkovskiy, M. (2006). Hotel services marketing. Moscow: Finances and statistics.

Volkov, S.K. (2009, January-March). „All inclusive” system as a factor of tourism development in the Russian Federation. Bulletin of the National Academy of Tourism, 1, 46-48.

Volkov, S.K. (2015). Culture as a factor in the formation of an attractive image of Russian territories. Regional economy: theory and practice, 13, 60-67.

Volkov, S.K. (2015). Foreign experience of territory promotion. Society and economy, 1-2, 196202.

Volkov, S.K. (2016). German experience in tourism development. Contemporary Europe, 5, 115122.

Williams, A.P. \& Palmer, A.J. (1999). Tourism destination brands and electronic commerce: Towards synergy? Journal of Vacation Marketing, 5(3), 263-275.

World Bank. (2016). The Little Data Book 2016. Washington, D.C.: Author.

Yankevich, B.C. \& Bezrukova N.L. (Ed.). (2003). Marketing in the hotel industry and tourism: Russian and international experience. Moscow: Finances and statistics. 